\title{
Reproductive biology and pollination of Aechmea distichantha Lem. (Bromeliaceae)
}

\author{
Gilson João Scrok ${ }^{1}$ and Isabela Galarda Varassin ${ }^{2,3}$
}

Recebido em 23/06/2010. Aceito em 8/06/2011

\begin{abstract}
RESUMO
(Biologia reprodutiva e polinização em Aechmea distichantha Lem. (Bromeliaceae)). A biologia reprodutiva, incluindo fenologia, biologia floral, polinização e sistemas reprodutivos foram estudados em Floresta com Araucária no Paraná. A fenologia e reprodução de plantas terrícolas foram acompanhadas em outubro 2006 e de maio a outubro de 2007. O pico de floração ocorreu de junho a setembro e a frutificação de junho a outubro. A antese durou um dia. As flores foram polinizadas principalmente por Stephanoxis lalandi e a borboleta mais freqüente foi Lychnuchoides ozias ozias. A concetração de nectar declinou durante a antese, enquanto que o volume de néctar permaneceu constante. Aechmea distichantha é auto-compatível com 30-45\% de frutificação nos testes de autopolinização. A luz solar influenciou a reprodução: quando controlados o tamanho das bromélias e das inflorescências, plantas no sol produziram mais sementes por frutos que plantas na sombra. A reprodução também foi associada com tamanho das inflorescências quando controlado o tamanho da bromélia. Inflorescências maiores em plantas de mesmo tamanho produzem mais flores e mais sementes por fruto.
\end{abstract}

Palavras-chave: beija-flores, biologia floral, borboletas, fenologia floral, sistemas reprodutivo

\begin{abstract}
(Reproductive biology and pollination of Aechmea distichantha Lem. (Bromeliaceae)). Reproductive biology, including phenology, flower biology, pollination, and the reproductive system in the bromeliad Aechmea distichantha were studied in an Araucaria forest in the state of Paraná. Phenology and reproduction in terricolous plants were followed in October 2006 and May - October of 2007. Flowering peaked from June to September and fruiting was from June to October. Flower anthesis lasted one day. Flowers were pollinated the most by the hummingbird Stephanoxis lalandi and the most common butterfly visitor was Lychnuchoides ozias ozias. Nectar concentration declined during anthesis, while nectar volume was constant. Aechmea distichantha is self-compatible with $30-45 \%$ fruit formation in self-pollination tests. Sunlight influences reproduction: when controlling for bromeliad and inflorescence size, plants in sunlight produced more seeds per fruit than plants in the shade. Reproduction was also associated with inflorescence size when controlling for bromeliad size. That is, larger inflorescences in similar sized plants produced more flowers and more seeds per fruit.
\end{abstract}

Key words: breeding systems, floral phenology, floral biology, hummingbirds, butterflies

\section{Introduction}

Bromeliaceae is a large family of monocotyledons in which the majority of species are pollinated by hummingbirds (Martinelli 1997; Buzato et al. 2000; Varassin \& Sazima 2000; Kaehler et al. 2005; Machado and Semir 2006; Piacentini \& Varassin 2007) but bats may also be important (Sazima et al. 1995; Sazima et al. 1999). Insects may also pollinate these plants, yet this is seldom demonstrated (Benzing
2000; Varassin \& Sazima 2000; Siqueira Filho \& Machado 2001; Kaehler et al. 2005; Lenzi et al. 2006). Also, insect pollination is often in association with other pollinating animals (Benzing 2000; Varassin \& Sazima 2000; Siqueira Filho \& Machado 2001; Wendt et al. 2001; Lenzi et al. 2006) and hence may confuse the true source of pollination.

The Bromeliaceae comprise a wide variety of reproductive systems. Selfing has been found in most species and in several genera, including Aechmea, Alcantarea, Billbergia,

1 Universidade Tuiuti do Paraná, Curitiba, PR, Brazil

2 Universidade Federal do Paraná, Centro Politécnico, Departamento de Botânica; Setor de Ciências Biológicas, Laboratório de Ecologia Vegetal, Curitiba, PR, Brazil

3 Autor para correspondência: isagalarda@ufpr.br 
Canistrum, Pitcairnia and Vriesea (Martinelli 1997; Siqueira Filho \& Machado 2001; Wendt et al. 2001; Wendt et al. 2002; Lenzi et al. 2006; Paggi et al. 2007), yet incompatibility systems are also found in Aechmea, Billbergia and Quesnelia (Martinelli 1997; Canela \& Sazima 2003). Spatial and temporal mechanisms to avoid selfing include dichogamy, dioecy and herkogamy (Martinelli 1997; Siqueira Filho \& Machado 2001). However, these mechanisms to avoid selfing are not always effective due to the behavior of the pollinating animals (Siqueira Filho \& Machado 2001).

Reproduction may also be influenced by the environment in which the plant is found and in which resource availability may vary (Lechowicz \& Bell 1991). Environmental variation may also influence fitness by affecting the number and abundance of pollinating species (Herrera 1995). In the Bromeliaceae, environmental variation can influence reproductive success within and among populations (Paggi et al. 2007). For example, light regime can influence individual size and consequently their reproductive success (Lenzi et al. 2006). Small scale variation, such as flower numbers and density, can influence visitation by pollinators and hence influence reproductive success (Grindeland et al. 2005; Makino et al. 2007).

Here we examine reproductive biology of the bromeliad Aechmea distichantha Lem. This bromeliad is common in the Atlantic Rain Forest and is considered a generalist or pioneer epiphyte (Borgo \& Silva 2003). Specifically, we examine phenology, floral biology and the reproductive system to examine how variation in the local environment may influence reproductive success, in southern Brazil.

\section{Materials and methods}

Aechmea distichantha was studied at the Gruta de Bacaetava Municipal Park (GBMP) (2513'54”S, 49¹2’26”W). Created in May 2000, the park comprises an area of 17.4 ha, in Colombo, in the southern Brazilian state of Paraná. The climate is subtropical, with an annual average temperature of $16^{\circ} \mathrm{C}$ and $1450 \mathrm{~mm}$ average rainfall, in an Araucaria forest (Prefeitura Municipal de Colombo 1999).

We studied terricolous plants of Aechmea distichantha. Plants were visited weekly during two phases. The first, in October 2006 was to observe flower visitors. The second, May - October 2007, included observations of flower visitors and the experimental study. Twenty plants that were available on the ground were studied weekly through the flowering period to record flowering phenology, morphology and biology. The number of flowers in each inflorescence was counted and the duration of time over which the flower was open was registered. The plants occurred in two different light environmental settings: open areas (considered here as a sunny environment) or in forest understory (considered here as a shade environment).

To compare productivity in different light environmental settings and with different pollinators, we must first con- trol for local variation among plants. First, plant size may confound comparisons of seed set if larger plants produce more. Similarly, larger plants may have larger flowers and so on. Thus, we estimated plant size by measuring each plant. The radius ( $r$ ) of the plant was estimated by measuring the length of the external-most leaf of the rosette from the base to the tip. Plant height (h) was the length of the most internal leaf near the floral scape. Plant size was estimated using those two measurements as radius and height in the formula for the volume of a cylinder $\left(4 / 3 \pi r^{3} h\right)$. Similarly, radius and height of the inflorescence were measured and used to calculate volume as an estimate of inflorescence size.

We tested whether light regime influenced reproductive success, as other studies have shown that pollination success is greater under lighter conditions. Since larger plants produce larger inflorescences and larger inflorescences produce more flowers, we must first control for plant size. Using regression analysis, we estimated the relationship between bromeliad size and inflorescence size (Zar 1999). From that regression, we used the residuals to examine how inflorescence size influences productivity, as if we were comparing inflorescence size among similarly-sized bromeliads. Similarly, we also examined whether fruit production was due to the number of flowers, controlling for inflorescence size. That is, if all inflorescence were the same size, do those with more flowers produce more fruits? While this may seem obvious, it may not be the case if fruit abortion is common. The number of flowers and fruits were counted in 20 individual plants. Seeds were counted from five fruits per plant. We tested whether light regime (plant in full sun exposure or plant in forest understory) influenced reproductive success as the number of fruits and seeds produced per plant, controlling for number of flowers per inflorescence by a covariance analysis.

Breeding system experiments comprised manipulations to test how pollination influences fruit production: 1) Open pollination (flowers were not manipulated), 2) apomixis (flowers were emasculated and the stigma removed), 3) autonomous pollination, 4) selfing and 5) crossing (Radford et al., 1974). Reproductive success, measured as fruit set, was compared among treatments by independence tests using contingency tables (Zar 1999).

Plants were observed in the field to attempt to discover which animals were pollinators. Flowers were observed with binoculars during bouts of approximately $4 \mathrm{~h}$ in the morning. Some flower visitors were photographed. Visits and time duration were noted. Hummingbirds were identified from field guides while invertebrates were collected and identified by specialists. We avoided observing visitors more than once at the same plant (Kaehler et al. 2005).

Nectar was collected, with capillary tubes from flowers that were previously covered by small bags to prevent removal by animals, from 12 plants every hour on the hour from 07:00 - 17:00h. Therefore, nectar samples are the cumulative production during the time interval while they 
were sacked. We registered date, time, temperature, relative humidity, and nectar volume at each collection. Samples were then frozen for later analysis. Volume was measured with a Hamilton $50 \mu \mathrm{l}$ microsyringe and sugar concentration was measured with an Atago portable refractometer. Nectar production was tested for partial correlations with temperature, humidity and time of day (Zar 1999).

\section{Results}

Plant diameter varied from $140-280 \mathrm{~cm}($ mean $=193$ $\mathrm{cm})$ and height from $50-100 \mathrm{~cm}($ mean $=68.5 \mathrm{~cm})$. The inflorescence is a spike, pinkish with bluish petals. Formation of the scape ( $25-45 \mathrm{~cm}$ long) takes around 60 days. Fruit $\left(60-310\right.$ inflorescence $\left.^{-1}\right)$ formation is complete approximately 40 days after flowering. Inflorescence height varied between $10-22 \mathrm{~cm}$ and diameter $7-10 \mathrm{~cm}$. On average there were 129 flowers inflorescence ${ }^{-1}$ and fruit set of 120 seeds fruit ${ }^{-1}$. This production results in an average of 15,480 seeds inflorescence ${ }^{-1}$.

The peak flowering period of Aechmea distichantha was June - September 2007, with approximately 10 simultaneous plants flowering month $^{-1}$. Inflorescences lasted 20 - 30 days and the number of flowers per inflorescence was $70-330$, with $5-10$ open flowers inflorescence ${ }^{-1}$ at any given moment. Anthesis began between 05:00 - 06:00h and ended 17:00 - 18:00h on the same day. Fruit were found from June - October.

When reproductive success was calculated after controlling for plant size, we first found that larger inflorescences produced a larger number of flowers (ln number of flowers $=5.0+0.65 \mathrm{x}$ residual inflorescence volume, $r^{2}=0.28, F=$ $8.42, \mathrm{df}=1,18, p<0.05)$. However, neither the size of the inflorescence nor the number of flowers per inflorescence was influenced by light regime (after controlling for the size of the bromeliad, $t<1.0, \mathrm{df}=18, p>0.10$ ). However, the number of fruit produced per plant was much greater in the sun than in the shade, after controlling for number of flowers per inflorescence $(t=3.66, \mathrm{df}=18, p<0.05$, Fig. $1 \mathrm{~A})$ and the number of seeds produced per fruit was greater in the sun than shade $(t=2.83, \mathrm{df}=18, p<0.05$, Fig. $1 \mathrm{~B})$. Therefore, controlling for plant and inflorescence size, we found that more seeds are produced per fruit in the sun.

Aechmea distichantha can be self-compatible, as fruit production in the self-pollination tests was $30-45 \%$ (Tab. 1). Fruit set in natural conditions was $80 \%$ (Tab. 1). Fruit set was lowest in apomixis $\left(10 \%, \chi^{2}=24.0, \mathrm{df}=4, p<0.05\right)$ with few seeds per fruit. Fruit set was more or less equal among the autonomous, selfing and crossing treatments $\left(\chi^{2}=1.82\right.$, $\mathrm{df}=2, p>0.05$, Tab. 1$)$.

Of the 200 observed visits to flowers during 65 hours of observation, $33 \%$ were hummingbirds and $68 \%$ were butterflies (Tab. 2). Stephanoxis lalandi lalandi (Vieillot, 1818) was the most commonly observed hummingbird, accounting for $57 \%$ of the visits, followed by Thalurania glaucopis (Gmelin, 1788) (26\%, Tab. 2). Of the butterflies, Lychnuchoides ozias ozias (Hewiton, 1878) was the most common (50\%), followed by Heliconius ethila narcaea (Godart, 1819) and Phoebis neocypris (Hübner, 1823) (Tab. 2). While hummingbirds visited at any time during flowering, butterflies were most observed during June and July, and seemed to be tied to climatic conditions (clear days, warmer temperatures). The bee Trigona spinipes (Fabricius, 1793) was observed as a pollen collector, foraging and damaging the flowers and apparently interfering with the visits by the other species.

Hummingbirds and butterflies both may cause geitonogamy because they visit more than one flower inflorescence $^{-1}$. Butterflies forage slowly, spending up to $1 \mathrm{~min}$ flower ${ }^{-1}$, while hummingbirds usually visit a flower for less than 10s. Flowers in the open areas were visited more often (both, butterflies and hummingbirds) than plants in the understory condition.
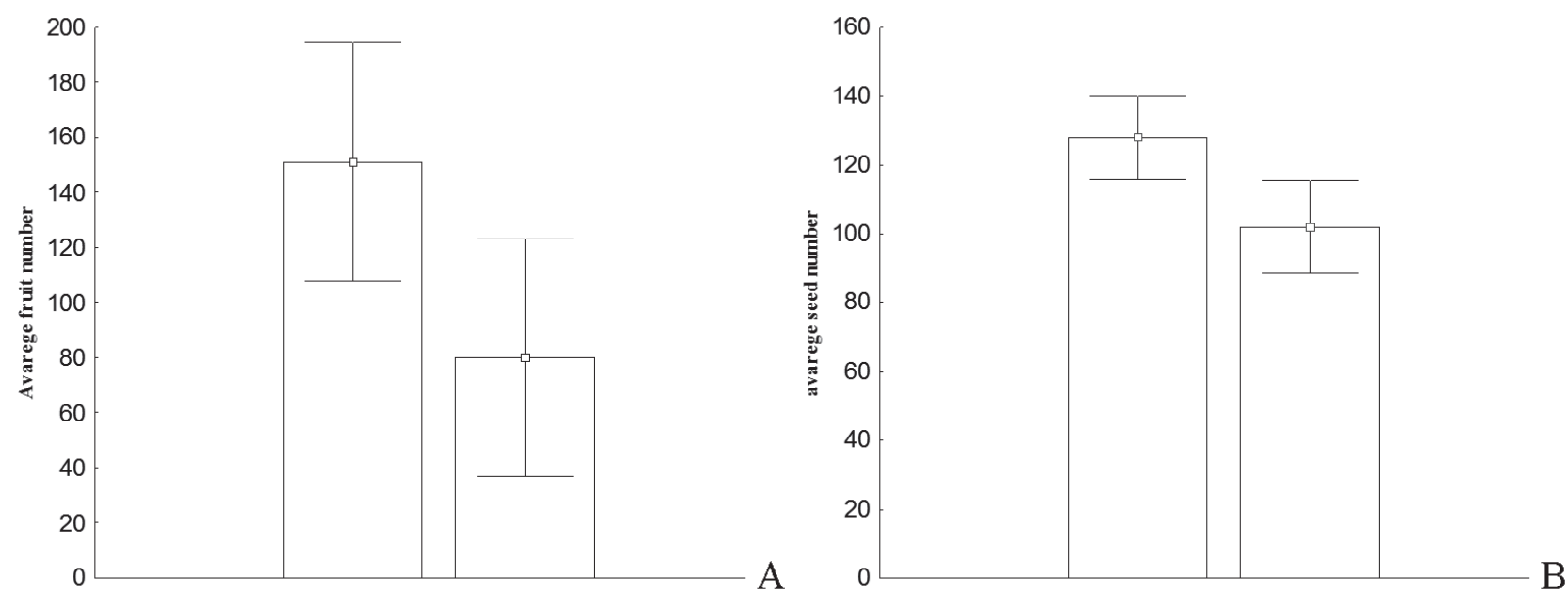

Figure 1. Average ( $+95 \%$ confidence interval for the mean) number of fruits (A) and seeds (B) produced in sunny (left) and shady conditions (right) in Aechmea distichantha. 
Table 1. Fruit set (\%) in the pollination treatments ( $\mathrm{n}=20$ flowers) in Aechmea distichantha.

\begin{tabular}{lc}
\hline Pollination Treatment & Fruit Set \\
\hline Autonomous & 30 \\
Selfing & 45 \\
Crossing & 50 \\
Open & 80 \\
Apomixis & 10 \\
\hline
\end{tabular}

Nectar content on average was $11.6 \mu \mathrm{l}(95 \% \mathrm{CI}=10.6$ - 12.7) and remained constant throughout anthesis $(r=$ 0.20 for correlation with hour of the day, $\mathrm{df}=40, p>0.05)$, indicating that production occurs only at the beginning of anthesis. Temperature and time were correlated $(r=0.60$, $\mathrm{df}=42, p<0.001)$ while humidity was independent of both temperature and time $(r=-0.12$, and $r=0.05$ respectively, $\mathrm{df}=42, p>0.05)$, therefore temperature and humidity were tested for a correlation with nectar production and concentration. Nectar volume was independent of both, temperature or humidity $(r=-0.30$ and 0.16 , respectively, $\mathrm{df}=40, p>0.05)$. Nectar concentration, however, was greatest during anthesis early in the morning after which it gradually decreased $(r=-0.58, \mathrm{df}=40, P<0.001)$. Concentration was correlated with temperature $(r=0.40$, $\mathrm{df}=40, P=0.0105)$, but not with humidity $(r=0.17, \mathrm{df}$ $=40, p>0.05$ ).

\section{Discussion}

Most plants in GBMP flowered in winter when rainfall was low, in contrast to reported flowering from January to April in Southeastern Brazil (Buzato et al. 2000). Plants with flowers pollinated by birds tend to flower during the wet season, with some species flowering throughout the year (Arizmendi \& Ornelas 1990; Sazima et al. 1995; Araújo et al. 2004). The extended flowering season of Aechmea distichantha favors visits by hummingbirds and butterflies. A consequence of this prolonged availability may keep pollinators in the area and thereby influence their availability to other species in the local plant community (Machado \& Semir 2006). In this study, $68 \%$ of flower visits were due to hummingbirds, which emphasizes their importance as pollinators (Benzing 2000, Siqueira \& Machado 2001; Lenzi et al. 2006). The use of bromeliads by both hummingbirds and butterflies is common and the butterflies seem to favor the genus Tillandsia (Varassin \& Sazima 2000).

Aechmea distichantha is facultatively selfing, sensu (Lima \& Vieira 2006), and may benefit from "reproductive assurance," since they may reproduce successfully even in the

Table 2. Visitation rates (flowers hour ${ }^{-1}$ ) among flower visitors at Aechmea distichanta in the GBMP.

\begin{tabular}{|c|c|c|c|c|c|c|c|}
\hline \multirow{2}{*}{ Pollinators (flower visitors) } & \multirow{2}{*}{$\begin{array}{c}2006 \\
\text { Oct }\end{array}$} & \multicolumn{4}{|c|}{2007} & \multirow{2}{*}{ Total } & \multirow{2}{*}{$\%$} \\
\hline & & Mai & Jun & $\mathrm{Jul}$ & Aug & & \\
\hline \multicolumn{8}{|l|}{ Hummingbirds } \\
\hline Aphantochroa cirrochloris $(\hat{\jmath})$ & & & & 0.06 & & 1 & 1.5 \\
\hline Chlorostilbon a. aureoventris (우) & 0.06 & & & & & 1 & 1.5 \\
\hline Leucochloris albicollis $(\widehat{\jmath})$ & 0.06 & & 0.04 & & & 2 & 3.1 \\
\hline Phaethornis pretrei $(\widehat{\oslash})$ & & 0.07 & 0.04 & 0.11 & 2.0 & 6 & 9.2 \\
\hline 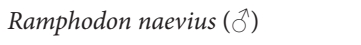 & & 0.07 & & & & 1 & 1.5 \\
\hline Stephanoxis lalandi $(9 ð)$ & 1.62 & 0.27 & 0.29 & & & 37 & 57 \\
\hline Thalurania glaucopis ( & 0.06 & 0.13 & 0.58 & & & 17 & 26.1 \\
\hline Monthly hummingbird total & 29 & 8 & 23 & 3 & 2 & 65 & \\
\hline \multicolumn{8}{|l|}{ Butterflies } \\
\hline Epityches eupompe & & 0.07 & & & & 1 & 0.7 \\
\hline Heliconius beschei & & 0.13 & 0.17 & & & 6 & 4.5 \\
\hline Heliconius ethilla narcaea & & 0.87 & 0.62 & & & 28 & 20.7 \\
\hline Hesperocharis erota & & & & 0.11 & & 2 & 1.5 \\
\hline Lychnuchoides ozias ozias & & & 2.79 & 0.06 & & 68 & 50.4 \\
\hline Phoebis neocypris & & & 0.17 & 0.83 & & 19 & 14.1 \\
\hline Vettius artona & & & 0.25 & & & 6 & 4.5 \\
\hline Vettius diversus & & & 0.21 & & & 5 & 3.7 \\
\hline Monthly butterfly total & 0 & 16 & 101 & 18 & 0 & 135 & \\
\hline Hours of observation & 16 & 15 & 24 & 9 & 1 & & \\
\hline
\end{tabular}


absence of pollinators (up to 30\%, Zhang \& Li 2007). Despite that self-compatibility is common in bromeliads (Martinelli 1997; Siqueira Filho \& Machado 2001; Lenzi et al. 2006), the importance of selfing has not been previously examined in the genus Platyaechmea. Fruit formation in the apomixy treatments indicates that asexual reproduction can occur. Low levels of apomixy were found in the genus Pitcairnia, with few and small seeds being produced as a consequence (Wendt et al. 2001). Thus, apomixy in that species plays a small role in reproduction, as with A. distichantha. Greater reproductive success in natural conditions (80\%) as compared to the experimental treatments was also found in Aechmea beeriana (98\%, Nara \& Webber 2002), Canistrum aurantiacum (89\%, Siqueira Filho \& Machado 2001) and in Vriesea longiscapa (86\%, Martinelli 1997). Greater success in control flowers may be due to lower rates of abortion than in manipulated flowers. It is more likely that the greater reproductive success in control flowers was due to the pollinator carrying pollen from a wide variety of source plants as observed by Kawai \& Kudo (2008), with greater genetic variability that may result in greater reproductive success. Such long distance gene flow may be due to pollinating species that travel large distances (Barbará et al. 2009).

Light environment directly influenced reproductive success in Aechmea distichantha: inflorescences in the sun had $180 \%$ more fruit and $120 \%$ more seeds than those in the shade. This may be due to resource allocation in response to photosynthetic constrains as evidenced by Cervantes et al. (2005). The larger production of fruits and seeds may be also affected by pollinator behavior since bromeliads in sunny places were visited more often. Pollinator foraging may be influenced by the environmental light (Kilkenny \& Galloway, 2008) and pollen limitation due to reduced pollinator visits may cause the variation in reproduction among bromeliad populations (Paggi et al. 2007). Since hummingbirds are very sensitive to environmental changes in resource supply (Cotton 2007) and avoid unrewarding patches (Sandlin 2000), they may have visited the bromeliads in sunny patches more often due to greater flower availability.

The volume of nectar produced in the morning remained constant throughout the day (when not removed by pollinators), similar to that found in Aechmea lindenii (Lenzi et al., 2006), which suggests that Aechmea distichantha only produces at the beginning of anthesis. On the other hand, concentration was greatest early, at the beginning of anthesis, and gradually declined. This suggests that the flower reabsorbs the solutes, as has been observed in other hummingbirds pollinated species (Freitas \& Sazima 2001; Varassin et al. 2001) including Bromeliaceae (Canela \& Sazima 2003). While concentration was independent of volume in A. distichantha, in A. pectinata both varied during anthesis (Canela \& Sazima 2003). In both cases, nectar quality (from the pollinator perspective) is greatest in the morning, which appears to be a common trend in the Bromeliaceae (Machado \& Semir 2006).
The greater rate of hummingbird visits in the morning is likely to be due to the greater quality of the nectar at that time (Canela \& Sazima 2003; Machado \& Semir 2006). On the other hand, butterfly visits were always associated with good climatic conditions (higher temperatures, no rain, pers. obs.).

Aechmea distichantha, while self-compatible, has greater reproductive success in natural conditions, perhaps due to pollinator efficiency and consequently greater outcrossing. The greater success in the sun also suggests that it is due to pollinator efficiency, as trap-lining hummingbirds are more likely to find the more visible flowers. Additionally, greater success in the sun may be the result of the combined benefit of greater resource allocation that also influences pollinator visitation.

\section{Acknowledgements}

The authors thank Miriam Kaehler, Eduardo Ramirez, James J. Roper and Juliana Quadros for the constructive suggestions for the quality of this manuscript; Ivana Gavassi Bilotta, Olaf Mielke and André Victor Lucci Freitas for indentifying the butterflies; the municipality of Colombo (Municipal Secretary of Tourism) for the permission to work in their areas; and J. Roper who translated this manuscript from Portuguese.

\section{References}

Araújo, A.C.; Fischer, E.A. \& Sazima, M. 2004. As bromélias na região do Rio Verde. Pp.162-171. In: Marques, O.A.V. \& Duleba, W. (Eds.). Estação Ecológica Juréia-Itatins. Ambiente físico, flora e fauna. São Paulo, Holos Editora.

Arizmendi, M.C. \& Ornelas, J.F. 1990. Hummingbirds and their floral resources in a tropical dry forest in Mexico. Biotropica 22(2): 172-180.

Barbará, T.; Martinelli, G.; Palma-Silva, C.; Fay, M.F.; Mayo, S.J. \& Lexer, C. 2009. Genetic relationships and variation in reproductive strategies in four closely related bromeliads adapted to neotropical 'inselbergs': Alcantarea glaziouana, A. regina, A. geniculata and A. imperialis (Bromeliaceae). Annals of Botany 103(1): 65-77.

Benzing, D.H. 2000. Bromeliaceae: profile of an adaptative radiation. Cambridge, Cambridge University Press.

Borgo, M. \& Silva, S.M. 2003. Epífitos vasculares em fragmentos de Floresta Ombrófila Mista, Curitiba, Paraná, Brasil. Revista Brasileira de Botânica 26(3): 391-401.

Buzato, S.; Sazima, M. \& Sazima, I. 2000 Hummingbird-pollinated floras at three Atlantic forest sites. Biotropica 32(4): 824-841.

Canela, M.B.F. \& Sazima, M. 2003. Aechmea pectinata: a hummingbirddependent bromeliad with inconspicuous flowers from the rainforest in south-eastern Brazil. Annals of Botany 92(5): 731-737.

Cervantes, S.E.; Graham, E.A. \& Andrade, J.L. 2005. Light microhabitats, growth and photosynthesis of an epiphytic bromeliad in a tropical dry forest. Plant Ecology 179(1): 107-118.

Cotton, P.A. 2007. Seasonal resource tracking by Amazonian hummingbirds. Ibis 149(1): 135-142.

Freitas, L. \& Sazima, M. 2001. Nectar features of Esterhazya macrodonta a hummingbird-pollinated Scrophulariaceae in Southeastern Brazil. Journal of Plant Research 114(2): 187-191.

Grindeland, J.M.; Sletvold, N. \& Ims, R.A. 2005. Effects of floral display size and plant density on pollinator visitation rate in a natural population of Digitalis purpurea. Functional Ecology 19(3): 383-390. 
Herrera, C.M. 1995. Microclimate and individual variation in pollinators: flowering plants are more than their flowers. Ecology 76(5): 1516-1524.

Kaehler, M.; Varassin, I.G. \& Goldenberg, R. 2005. Polinização em uma comunidade de bromélias em Floresta Atlântica Alto-montana no Estado do Paraná, Brasil. Revista Brasileira de Botânica 28(2): 219-228.

Kawai, Y. \& Kudo, G. 2008. Effectiveness of buzz pollination in Pedicularis chamissonis: significance of multiple visits by bumblebees [online] Ecological Research doi:10.1007/s11284-008-0500-6.

Kilkenny, F.F. \& Galloway, L.F. 2008. Reproductive success in varying light environments: direct and indirect effects of light on plants and pollinators. Oecologia 155(2): 247-255.

Lechowicz, M.J. \& Bell, G. 1991. The ecology and genetics of fitness in forest plants. II. Microspatial heterogeneity of the edaphic environment. Journal of Ecology 79(3): 687-696.

Lenzi, M.; Matos, J.Z. \& Orth, A.I. 2006. Variação morfológica e reprodutiva de Aechmea lindenii (E. Morren) Baker var. lindenii (Bromeliaceae). Acta Botanica Brasilica 20(2): 487-500.

Lima, N.A.S. \& Vieira, M.F. 2006. Fenologia de floração e sistema reprodutivo de três espécies de Ruellia (Acanthaceae) em fragmento florestal de Viçosa, Sudeste brasileiro. Revista Brasileira de Botânica 29(4): 681-687.

Machado, C.G. \& Semir, J. 2006. Fenologia da floração e biologia floral de bromeliáceas ornitófilas de uma área da Mata Atlântica do Sudeste brasileiro. Revista Brasileira de Botânica 29(1): 163-174.

Makino, T.T.; Ohashi, K. \& Sakai, S. 2007. How do floral display size and the density of surrounding flowers influence the likelihood of bumble bee revisitation to a plant? Functional Ecology 21(1): 87-95.

Martinelli, G. 1997. Biologia Reprodutiva de Bromeliaceae na Reserva Ecológica de Macaé de Cima. Pp. 213-250. In: Lima, H.C. \& GuedesBruni, R.R. (Eds). Serra de Macaé de Cima: Diversidade florística e conservação em Mata Atlântica. Rio de Janeiro, Jardim Botânico do Rio de Janeiro.

Nara, A.K. \& Webber, A.C. 2002. Biologia Floral e Polinização de Aechmea beeriana (Bromeliaceae) em Vegetação de Baixio na Amazônia Central. Acta Amazonica 32(4): 571-588.

Paggi, G.M.; Palma-Silva, C.; Silveira, L.C.T.; Kaltchuk-Santos, E.; Bodanese-Zanettini, M.H. \& Bered, F. 2007. Fertility of Vriesea gigantea Gaud. (Bromeliaceae) in southern Brazil. American Journal of Botany 94(4): 683-689.
Piacentini, V.Q. \& Varassin, I.G. 2007. Interaction network and the relationships between bromeliads and hummingbirds in an area of secondary Atlantic rain forest in southern Brazil. Journal of Tropical Ecology 23(6): 663-671.

Prefeitura Municipal de Colombo. 1999. Plano de Manejo do Parque Municipal da Gruta do Bacaetava. Colombo, PMC.

Radford, A.E.; Dickison, W.C.; Massey, J.R.; Bell, R.C. \& Seiler, M.S. 1974. Vascular plant systematics. New York, Harper and Row.

Sandlin, E.A. 2000. Cue use affects resource subdivision among three coexisting hummingbird species. Behavioral Ecology 11(5): 550-559.

Sazima, M.; Buzato, S. \& Sazima, I. 1995. Polinização de Vriesea por morcegos no sudeste brasileiro. Bromélia 2(1): 29-37.

Sazima, M.; Buzato, S. \& Sazima, I. 1999. Bat-pollinated flower assemblages and bat visitors at two Atlantic Forest Sites in Brazil. Annals of Botany 83(6): 705-712.

Siqueira Filho, J.A. \& Machado, I.C.S. 2001. Biologia reprodutiva de Canistrum aurantiacum E. Morren (Bromeliaceae) em remanescente da Floresta Atlântica, Nordeste do Brasil. Acta Botanica Brasilica 15(3): 427-443.

Varassin, I.G. \& Sazima, M. 2000. Recursos de Bromeliaceae utilizados por beija-flores e borboletas em Mata Atlântica no Sudeste do Brasil. Boletim do Museu de Biologia Mello Leitão (Nova Série) (11/12): 57-70.

Varassin, I.G.; Trigo, J.R. \& Sazima, M. 2001. The role of nectar production, flower pigments and odour in the pollination of four species of Passiflora (Passifloraceae) in south-eastern Brazil. Botanical Journal of the Linnean Society 136(2):139-152.

Wendt, T.; Canela, M.B.F.; Faria, A.P.G. \& Rios, R.I. 2001. Reproductive biology and natural hybridization between two endemic species of Pitcairnia (Bromeliaceae). American Journal of Botany 88(10): 1760-1767.

Wendt, T.; Canela, M.B.F.; Klein, D.E. \& Rios, R.I. 2002. Selfing facilitates reproductive isolation among three sympatric species of Pitcairnia (Bromeliaceae). Plant Systematics and Evolution 232(3-4): 201-212.

Zhang, Z. \& Li, Q. 2008. Autonomous selfing provides reproductive assurance in an Alpine Ginger Roscoea schneideriana (Zingiberaceae). Annals of Botany 102(4): 531-538.

Zar, J.H. 1999. Biostatistical Analysis. New Jersey, Prentice-Hall International Inc. 